\title{
A Partial Order for Genes Determining Enzymes of the meta-Cleavage Pathway in Pseudomonas putida
}

\author{
By G. J. WIGMORE* AND R. C. BAYLY \\ Department of Microbiology, Monash University Medical School, \\ Commercial Road, Prahran, 318I, Victoria, Australia
}

(Received 4 October 1976; revised 2 December 1976)

SUMMARY

A partial order for genes which specify meta-cleavage pathway enzymes has been derived from properties of a polarity mutant strain (PsU5) of Pseudomonas putida NCIBIOOI5 and a partial revertant, PsU5/R2I. The polar mutation is within the 2-hydroxymuconic semialdehyde dehydrogenase gene and results in loss of detectable 2-hydroxymuconic semialdehyde hydrolase and 90 to $95 \%$ reduction in the activities of 4-oxalocrotonate tautomerase, 4-oxalocrotonate decarboxylase, 2-oxopent-4-enoate hydratase and 4-hydroxy-2-oxovalerate aldolase. The partial revertant PsU5/R2 I regained wild-type levels of all enzymes except the aldehyde dehydrogenase.

It is probable that all genes determining the dehydrogenase and subsequent enzymes are transcribed as a polycistronic message. This is the first report of mapping genes determining the enzymes of the meta-cleavage pathway.

\section{INTRODUCTION}

Transduction, conjugation and transformation have been demonstrated in various species of fluorescent pseudomonads (Holloway, 1975; Stanisich \& Richmond, 1975) but a system of recombination has not been established for Pseudomonas putida NCIBIOOI5 (strain U) (Wigmore, 1975). Gene order may also be elucidated and confirmed by deletion mapping (Wheelis \& Ornston, 1972) and from studies of polarity mutants (Ornston, 1966).

Pseudomonas putida NCIBIOOI 5 grows at the expense of phenol and the isomers of cresol following meta-cleavage of catechol and the methylcatechols respectively. A pleiotropic mutation within the genes determining the enzymes of the meta-cleavage pathway has been reported which is consistent with a polarity mutation (Bayly \& Wigmore, 1973). The present work describes how this mutant, $\mathrm{PsU}_{5}$, carrying the pleiotropic mutation, was used to investigate an order for genes determining enzymes of the meta-cleavage pathway.

\section{METHODS}

Some properties of wild-type Pseudomonas putida NCIBIOOI5, designated PsUo, the pleiotropic mutant $\mathrm{PsU}_{5}$ and the partial revertant $\mathrm{PsU}_{5} / \mathrm{R}_{2} \mathrm{I}$ have been reported previously (Bayly \& Wigmore, 1973). Organisms were grown and extracts were prepared as described by Bayly \& Wigmore (1973). All enzymic activities were determined as reported by Wigmore \& Bayly (1974) except 4-hydroxy-2-oxovalerate aldolase which was determined as described by Feist \& Hegeman (1969).

* Present address: Department of Biochemistry, School of Medicine, University of Miami, Florida, U.S.A. 


\title{
Table I. Activities of enzymes of the meta-cleavage pathway in extracts of phenol-induced strains
}

\begin{abstract}
Extracts were assayed for enzymic activities $2 \mathrm{~h}$ after phenol $(2.5 \mathrm{~mm})$ was added to organisms growing in basal medium containing fumarate ( $10 \mathrm{mM})$. No activities were detected without phenol induction. Specific activities (except for tautomerase and decarboxylase) are expressed as nmol substrate used or product formed $\mathrm{min}^{-1}(\mathrm{mg} \text { protein })^{-1}$. Tautomerase activity is expressed as units of activity, where I unit represents the decrease of one absorbance unit at $295 \mathrm{~nm} \mathrm{~min} \mathrm{mg}^{-1}(\mathrm{mg}$ protein $)^{-1}$. Decarboxylase activity is expressed as: ++ , activity induced in the wild-type strain; , \pm 5 to $10 \%$ of the activity induced in the wild-type strain.
\end{abstract}

\begin{tabular}{lccc} 
& \multicolumn{3}{c}{ Strain } \\
Enzyme & PsUo & PsU5 & PsU5/R2 I \\
2,3-Oxygenase & I40 & 70 & I30 \\
Dehydrogenase & I9 & ND & ND \\
Hydrolase & 53 & ND & 53 \\
Tautomerase & I & O.I & I.I \\
Decarboxylase & ++ & \pm & ++ \\
Hydratase & 730 & 52 & 690 \\
Aldolase & 8 & I & 7 \\
& ND, Not detected. &
\end{tabular}

\section{RESULTS AND DISCUSSION}

The mutational defect in mutant $\mathrm{PsU}_{5}$ resulted in either the complete loss or a considerable reduction in the activity of the six enzymes of the meta-cleavage pathway acting later in the degradative sequence than catechol 2,3-oxygenase (Table I). The frequency of appearance of complete revertants (Bayly \& Wigmore, 1973) and the residual activity of several enzymes in mutant $\mathrm{PsU}_{5}$ are inconsistent with either multiple mutations or a deletion mutation. The phenotype of mutant $\mathrm{PsU}_{5}$ is unlikely to be due to a regulatory defect as it is not possible to propose a simple model to account for the partial revertant, in which only the dehydrogenase is inactive. It is also difficult to reconcile a regulatory mutation with partial loss of some enzymic activities and complete loss of others.

The most probable explanation of the pleiotropy of mutant PsU5 is that the phenotype is a consequence of premature termination of either transcription or translation. The residual activities in mutant PsU5 would result from a low efficiency reinitiation of either transcription or translation respectively, and the partial revertants would be the consequence of the spontaneous creation of an internal reinitiation site.

On the basis of the explanation of polarity mutations proposed by Morse \& Guertin (I97I), termination of mRNA transcription is a less likely explanation of the behaviour of mutant $\mathrm{PsU}_{5}$ than premature termination of translation.

A system analogous to $\mathrm{Ps}_{5}$ has been reported in the his operon of Salmonella typhimurium. A frame-shift mutation located in the his $D$ gene reduced expression of the adjacent gene, hisC, by 98 to $99 \%$ but reduced the expression of subsequent genes by only $90 \%$ (Voll, 1967; Rechler \& Martin, 1970; Rechler et al., 1972). Reznikoff et al. (1974) proposed a model which explained these observations and also their observations of disproportionate production of $\beta$-galactosidase and thiogalactoside transacetylase in trp-lac fusion strains of Escherichia coli. The major premise of this model is that efficient transcription of an operon requires a minimum number of ribosome binding events to ensure propagation and/or protection of the mRNA.

The enzymic activities of mutant $\mathrm{PsU}_{5}$ are consistent with a polarity mutation within the genes determining either the dehydrogenase or hydrolase. To account for the phenotype of 


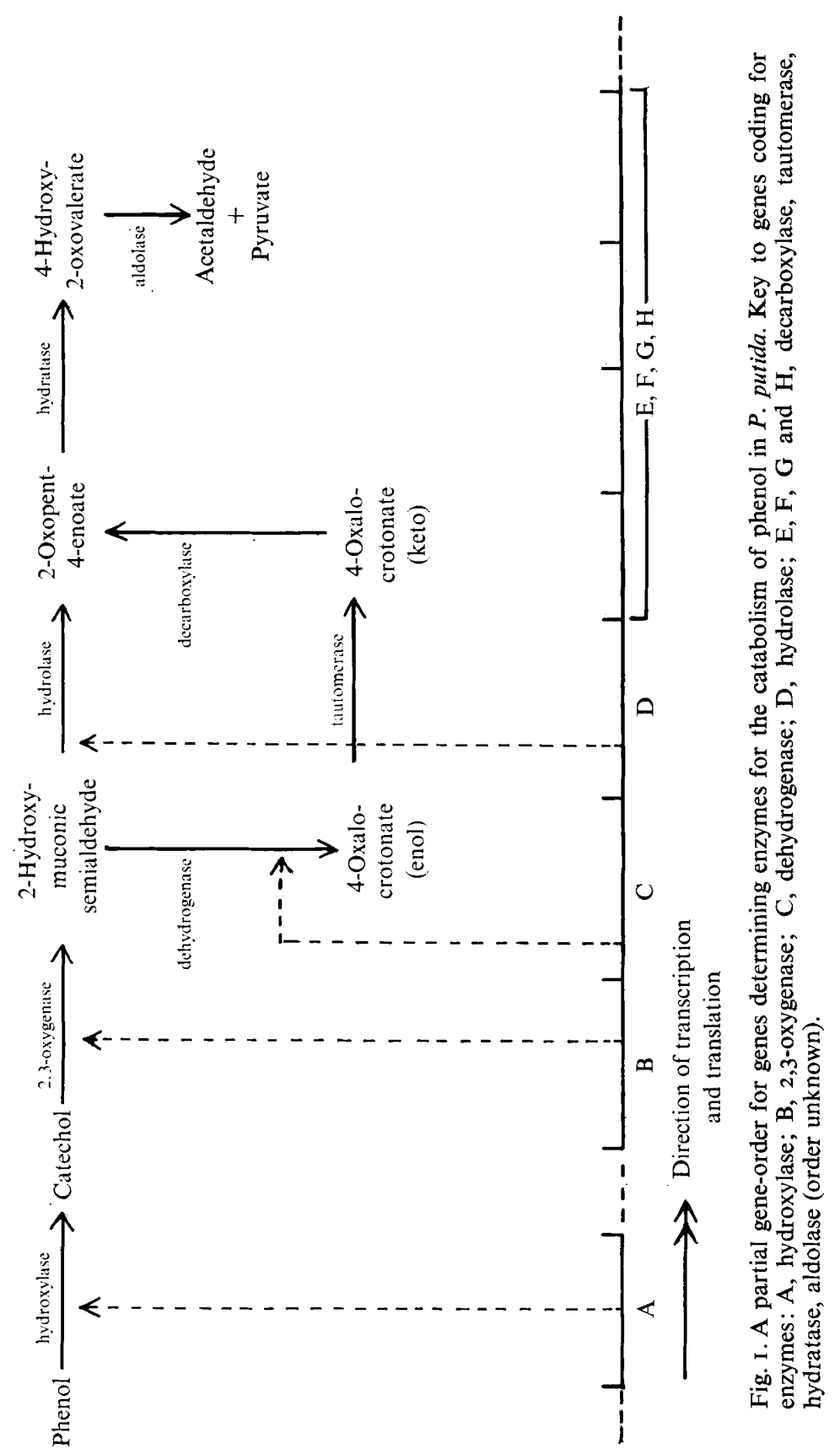


the partial revertants it is necessary to assume that the polar mutation is within the dehydrogenase gene and that the hydrolase is operator-distal. The partial revertants are explained by the creation of a new site for initiation of protein synthesis. Translational restarts within the lacI gene transcript of the lac operon can be created by the introduction of a nonsense codon before the initiation codon. Initiation occurred at both AUG (Platt et al., 1972) and non-AUG codons (Ganem et al., 1973; Files, Weber \& Miller, 1974).

Any explanation of the phenotype of mutant $\mathrm{PsU}_{5}$ and its partial revertant requires that the genes that determine the dehydrogenase and all subsequent enzymes are transcribed as a single polycistronic message. These explanations do not directly implicate the catechol 2,3-oxygenase gene transcript as part of this polycistronic message. However, there is no reason to exclude it, assuming this gene is at the operator-proximal end of the message. The coordinate expression of the catechol 2,3-oxygenase and subsequent enzymes (Bayly, Wigmore \& McKenzie, 1977) suggests that the catechol 2,3-oxygenase gene transcript is part of this polycistronic message. The gene determining phenol hydroxylase cannot form part of this operon because this enzyme is regulated independently of the remaining enzymes of the meta-cleavage pathway (Bayly et al., I977).

Although not demonstrated directly, it may be inferred that the gene determining the aldolase is at the operator-distal end of the polycistron. The aldolase gene is part of the polycistron since its expression is lowered by the polarity mutation. If the model of Reznikoff et al. (1974) is used to explain the phenotype of mutant $\mathrm{PsU}_{5}$ there will be reduced (but detectable) levels of all enzymes from cistrons after the termination signal except for the enzyme from the adjacent cistron which will not be detectable.

The partial gene-order for genes coding for enzymes of the meta-cleavage pathway (Fig. I) is consistent with the properties of mutant $\mathrm{PsU}_{5}$ and its partial revertant $\mathrm{PsU}_{5} / \mathrm{R} 2 \mathrm{I}$. The proposed partial gene-order can be tested and the gene-order further elucidated by deletion mapping.

The project was supported in part by grant no. D67/16545 from the Australian Research Grants Commission. We thank J. May and M. Barbour for helpful discussions.

\section{REFERENCES}

Bayly, R. C. \& Wigmore, G. J. (I973). Metabolism of phenol and cresols by mutants of Pseudomonas putida. Journal of Bacteriology II3, I I I 2-I I 20.

Bayly, R. C., Wigmore, G. J. \& MCKenzie, D. I. (I977). Regulation of the enzymes of the meta-cleavage pathway of Pseudomonas putida: the regulon is composed of two operons. Journal of General Microbiology roo, $7 \mathrm{I}-79$.

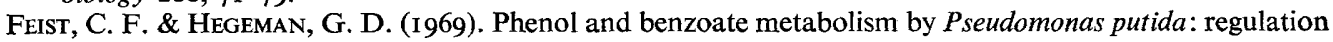
of tangential pathways. Journal of Bacteriology I00, 869-877.

FILES, J. G., WeBER, K. \& MilleR, J. H. (I974). Translational reinitiation: reinitiation of lac repressor fragments at three internal sites early in the lac $i$ gene of Escherichia coli. Proceedings of the National Academy of Sciences of the United States of America 71, 667-670.

Ganem, D., Miller, J. H., Files, J. C., Platt, T. \& Weber, K. (1973). Reinitiation of a lac repressor fragment at a codon other than AUG. Proceedings of the National Academy of Sciences of the United States of America 70, 3I65-3I69.

Holloway, B. W. (1975). Genetic organization of Pseudomonas. In Genetics and Biochemistry of Pseudomonas, pp. 133-16I. Edited by P. H. Clarke and M. H. Richmond. London: John Wiley.

MoRse, D. E. \& GuERTIN, M. (I97I). Regulation of mRNA utilization and degradation by amino-acid starvation. Nature New Biology 232, I65-I 69.

ORnston, L. N. (1966). The conversion of catechol and protocatechuate to $\beta$-ketoadipate by Pseudomonas putida. IV. Regulation. Journal of Biological Chemistry 241, 3800-3810.

Platt, T., Weber, K., Ganem, D. \& Miller, J. H. (1972). Translation restarts: AUG reinitiation of a lac repressor fragment. Proceedings of the National Academy of Sciences of the United States of America 69. $897-901$. 
RECHLER, M. M. \& MARTIN, R. G. (1970). The intercistronic divide: translation of an intercistronic region in the histidine operon of Salmonella typhimurium. Nature, London 226, 908-9I I.

Rechler, M. M., Bruni, C. B., Martin, R. G. \& Terry, W. (1972). An intercistronic region in the histidine operon of Salmonella typhimurium. Journal of Molecular Biology 69, 427-452.

Reznikoff, W. S., Michels, C. A., Cooper, T. G., Silverstone, A. E. \& Magasanik, B. (1974). Inhibition of lac $Z$ gene translation initiation in trp-lac fusion strains. Journal of Bacteriology $\mathbf{1 1 7}$, I23 I-I239.

Stanisich, V. A. \& Richmond, M. H. (1975). Gene transfer in the genus Pseudomonas. In Genetics and Biochemistry of Pseudomonas, pp. I63-190. Edited by P. H. Clarke and M. H. Richmond, London: John Wiley.

Voll, M. J. (1967). Translation and polarity in the histidine operon. III. The isolation of prototrophic polar mutants. Journal of Molecular Biology 30, 109-124.

Wheelis, M. L. \& OrNSton, L. N. (1972). Genetic control of enzyme induction in the $\beta$-ketoadipate pathway of Pseudomonas putida: deletion mapping of cat mutations. Journal of Bacteriology 109, 790-795.

Wigmore, G. J. (1975). Metabolism of phenol and cresols by mutant strains of Pseudomonas putida. Ph.D. thesis, Monash University, Australia.

Wigmore, G. J. \& BAyly, R. C. (I974). A mutant of Pseudomonas putida with altered regulation of the enzymes for degradation of phenol and cresols. Biochemical and Biophysical Research Communications 6o, $48-55$. 